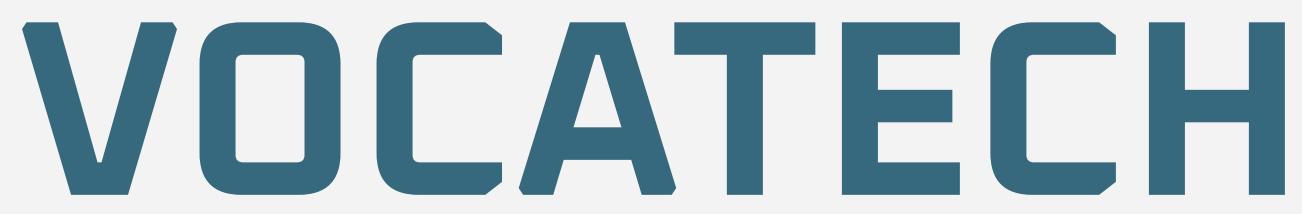

VOCATIONAL EDUCATION AND TECHNOLGY JOURNAL

Biannual

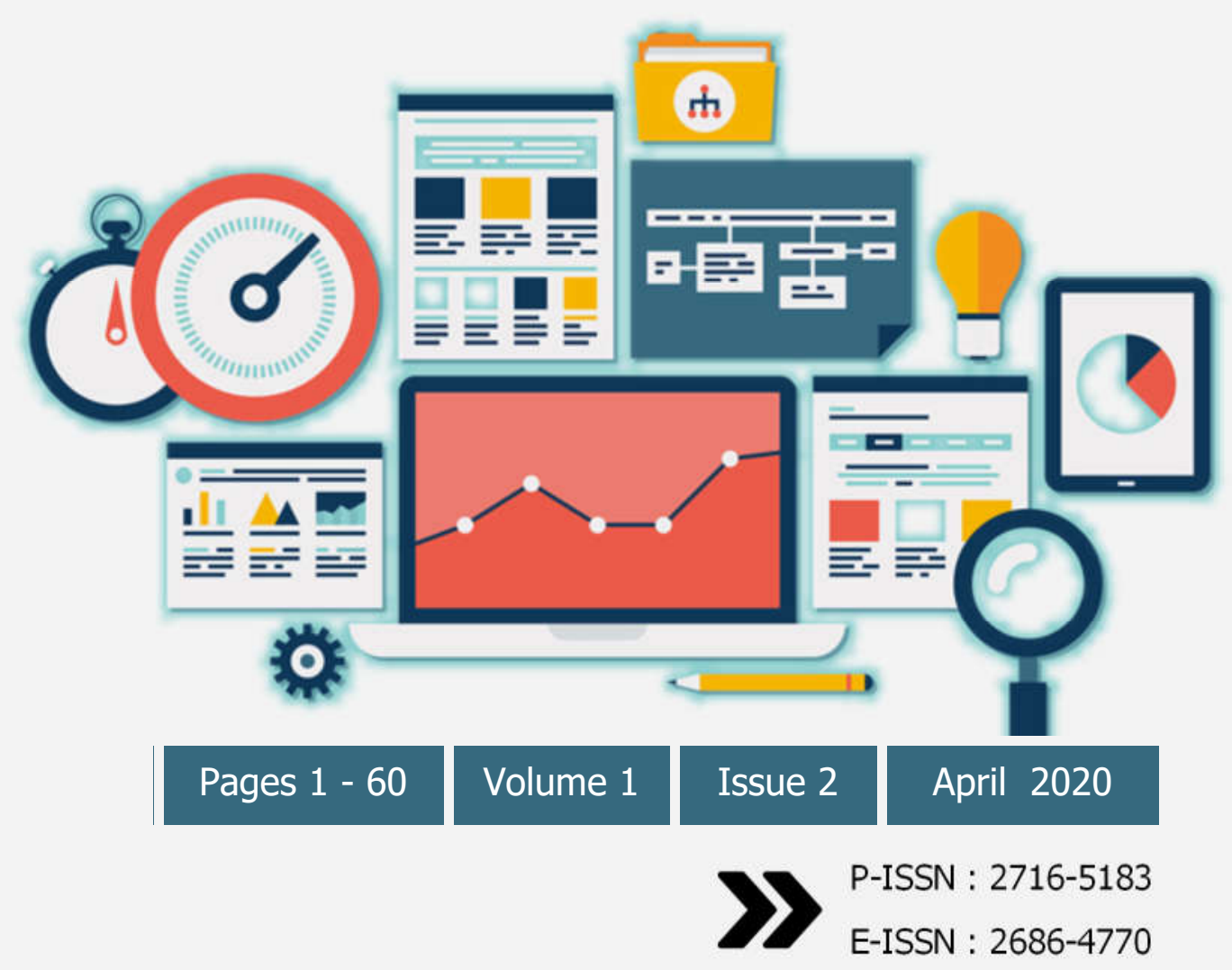

Published By: Unit Penelitian, Pengabdian Masyarakat dan Penjaminan Mutu Akademi Komunitas Negeri Aceh Barat

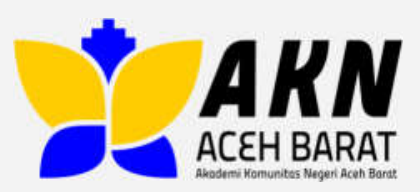




\section{P-ISSN : 2716-5183 \\ E-ISSN : 2686-4770

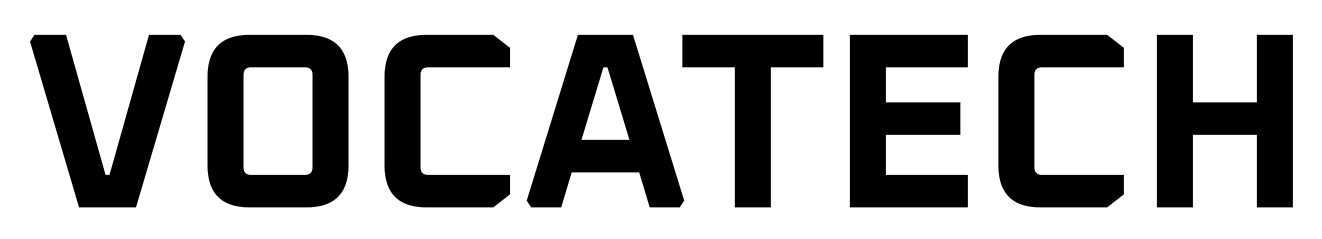

VOCATIONAL EDUCATION AND TECHNOLGY JOURNAL

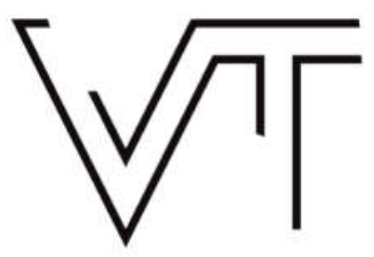

\section{Editorial Team}

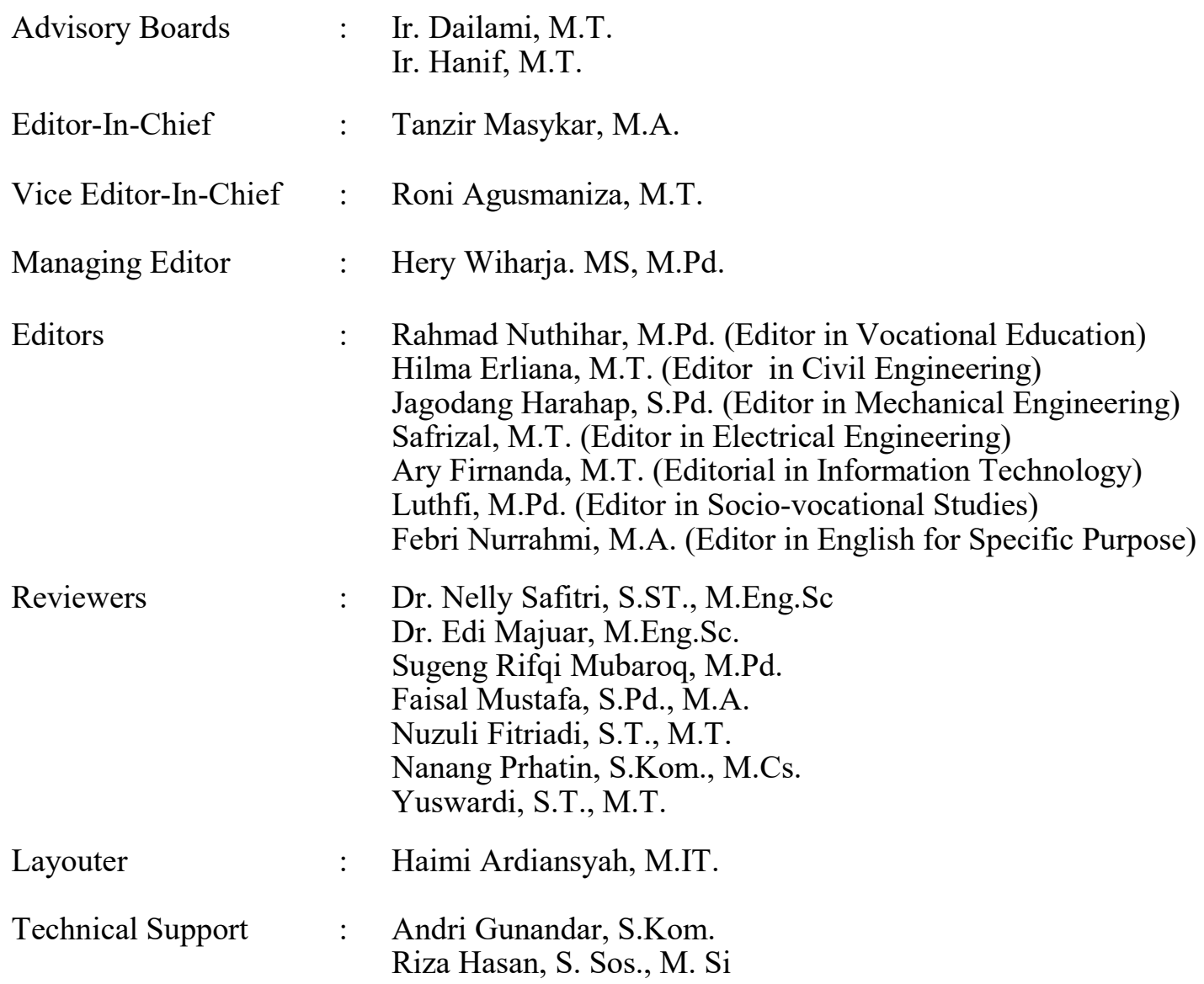

\section{Alamat Redaksi (Journal Address)}

Unit Penelitian, Pengabdian Masyarakat dan Penjaminan Mutu

Akademi Komunitas Negeri Aceh Barat

Komplek STTU Alue Peunyareng, Ujong Tanoh Darat, Meureubo, Kabupaten Aceh Barat, Aceh 23615, Indonesia

Website: http://ojs.aknacehbarat.ac.id/index.php/vocatech/index

Email:vocatech@akanacehbarat.ac.id 


\section{(2) \\ E-ISSN : 2686-4770

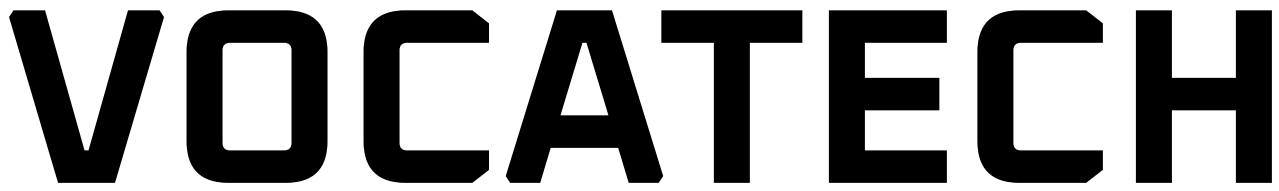 \\ VOCATIONAL EDUCATION AND TECHNOLGY JOURNAL}

\section{DAFTAR ISI (TABLE OF CONTENT)}

Pengaruh $R O E, D E R$, dan EPS Terhadap Harga Saham pada Emiten Syariah Sektor Barang

Konsumsi di BEI

—Dwi Meilvinasvita, Safaruddin, Yuliana—-

Penerapan General English dan English For Specific Purposes di Perguruan Tinggi Khususnya pada Pendidikan Vokasi

\section{—Rena Juliana, Reni Juliani-}

Pengaruh Penggunaan Kapasitor Bank pada Penyulang Kota di Pt. PLN (Persero) Rayon

Meulaboh Kota

-Haimi Ardiansyah-

Desain Alat Uji Impak Jatuh Bebas untuk Pengujian Baja Struktur

—Dailami, Hamdami, Samsul Bahri-

Analisis Kinerja Angkutan Kota dalam Provinsi di Provinsi Aceh Berdasarkan Pendekatan Load

Factor

—Ruhdi Faisal, Cut Mutiawati , Alfi Salmannur-

Klasifikasi Kematangan Buah Tomat dengan Variasi Model Warna Menggunakan Support Vector

Machine

\section{-Nica Astrianda-}

Implementasi Algoritma K-Mean dalam Pengelompokan Data Kecelakaan di Kabupaten Kediri

—Adimas Ketut Nalendra, M. Mujiono, Rafika Akhsani, Adiguna Sasama Wahyu U.- 


\title{
DESAIN ALAT UJI IMPAK JATUH BEBAS UNTUK PENGUJIAN BAJA STRUKTUR
}

\author{
Dailami* \\ Hamdani \\ Smasul Bahri \\ Politeknik Negeri Lhoksumawe, Aceh
}

\begin{abstract}
Impact testing is a test to measure material resistance to shock loads (dynamic). Impact testing simulates the material operating conditions often encountered when the load does not always occur slowly but rather comes suddenly. The impact test equipment to be designed in this study is a free-fall impact test. This impact test tool utilizes the mass of the object and the force of gravity. This test aims to analyze the effect of free fall impact loading on steel structures dropped from $1.5 \mathrm{~m}$ height. The steps taken in this study include testing and data collection to determine the energy absorbed, the impact price, momentum, impulse and toughness in steel structure material when given a shock load. In this free fall impact test, weight load is at $(m)=2.4 \mathrm{~kg}$ with an altitude distance of $(h)=1.5 \mathrm{~m}$. The test results showed that the maximum absorbable energy of structural steel is at $(E)=352.94 \mathrm{~J}$, the maximum impact value of structural steel at $(\mathrm{HI})=8.82 \mathrm{~J} / \mathrm{mm}$, the maximum momentum of structural steel at $(\mathrm{M}) 39.04 \mathrm{~kg} . \mathrm{m} / \mathrm{s}$ and the maximum implant steel structure at (I) 39.04 Ns. Mechanical behaviour is indicated by the bending of the specimen due to impact collision (striker) when testing is done.
\end{abstract}

Keywords:

Free-fall impact, Structure steel

\begin{abstract}
Abstrak
Pengujian impak merupakan suatu pengujian untuk mengukur ketahanan bahan terhadap beban kejut (dinamis). Pengujian impak mensimulasikan kondisi operasi material yang sering ditemui dimana beban tidak selamanya terjadi secara perlahan-lahan melainkan datang secara tiba-tiba. Alat uji impak yang akan dirancang dalam penelitian ini merupakan alat uji impak jatuh bebas. Alat uji impak ini memanfaatkan massa benda serta gaya gravitasi. Pengujian ini bertujuan untuk menganalisa pengaruh pembebanan impak jatuh bebas pada baja struktur yang dijatuhkan dari ke tinggian 1,5m. Langkah yang dilakukan dalam penelitian ini meliputi pengujian dan pengambilan data untuk mengetahui energi yang diserap, harga impak, momentum, implus dan ketangguhan pada material baja struktur saat diberi beban kejut. Pada pengujian impak jatuh bebas ini, mempunyai jarak dan berat beban yaitu pada beban $(\mathrm{m})=$ $2,4 \mathrm{~kg}$ dengan jarak ketinggian $(\mathrm{h})=1,5 \mathrm{~m}$. Dari hasil pengujian yang diperoleh energi yang diserap maksimum baja struktur $(\mathrm{E})=352,94 \mathrm{~J}$, harga impak maksimum baja struktur $(\mathrm{HI})=8,82 \mathrm{~J} / \mathrm{mm}^{2}$, momentum maksimum baja struktur (M) 39,04 kg.m/s dan implus maksimum baja struktur (I) 39,04 Ns. Perilaku mekanis ditunjukkan dengan terjadinya pembengkokan pada spesimen akibat benturan Beban (striker) saat pengujian dilakukan.
\end{abstract}

Kata Kunci:

Impak jatuh bebas, Baja struktur

Received: 3 March, 2020 ; Revised: 27 March, 2020 ; Accepted: 30 March, 2020

DOI: https://doi.org/10.38038/vocatech.v1i2.22

\footnotetext{
*Corresponding author:

Dailami, Jurusan Teknik Mesin, Politeknik Negeri Lhoksumawe, Jl. Banda Aceh-Medan Km. 280,3, Buketrata, Mesjid Punteut, Blang Mangat, Kota Lhokseumawe, Aceh 24301, Indonesia.

Email: dailamiteknik@gmail.com
}

Citation in APA Style: Dailami., Hamdani, \& Bahri, S., (2020). Desain alat uji impak jatuh bebas untuk pengujian baja struktur. VOCATECH: Vocational Education and Technology Journal, Vol. 2 (1), 28-36. 


\section{PENDAHULUAN}

\section{A. Latar Belakang}

Seseorang yang bergelut di bidang keteknikan pasti dihadapkan dengan sebuah pekerjaan yang berkenaan dengan pemilihan material untuk membuat sebuah kontruksi. Yang paling penting dalam sebuah perencanaan kontruksi adalah mengetahui sifat dan karakteristik dari material, salah satu cara untuk mengetahui karakteristik material adalah dengan pengujian impak. Pengujian impak dilakukan untuk mengetahui karakteristik material akibat pembebanan dinamis. Pengujian impak itu sendiri dapat dilakukan dengan beberapa metode seperti pengujian impak metode Charpy, metode Izod, metode benda jatuh bebas, dan lain-lain.

Untuk penggunaan sebagai bahan, sifat-sifat khas dari material logam harus diketahui sebab logam tersebut akan digunakan untuk berbagai macam keperluan dan keadaan. Sifat logam tersebut meliputi sifat mekanik, sifat thermal, sifat kimia, kemampukerasan, akurasi dimensi,dan lain sebagainya. Adapun dalam percobaan ini yang akan diuji adalah sifat mekanik dari logam terutama sifat ketangguhannya. Dengan mengetahui tingkat ketangguhan logam tentunya kita dapat memperkirakan kemampuannya dalam menerima energi tumbukan yang diberikan secara tiba-tiba untuk dapat mematahkan suatu material. Untuk keperluan itulah dilakukan pengujian impact pada suatu material atau bahan yang akan digunakan dalam berbagai macam kebutuhan.

Pengujian ini sangat penting dalam menentukan ketahanan terhadap suatu material dengan perpatahan, berdasarkan energi yang diberikan oleh tumbukan/pembebanan secara tibatiba pada suatu material. Setelah melukakan kajiankajian singkat kemudian peneliti berencana Untuk merancang dan melakukan pengujian impact pada material yang nantinya akan digunakan dalam konstruksi mesin guna meningkatkan kualitas suatu produk, terutama pada pipa-pipa gas dan tangki gas. Selain itu hasil dari penelitian ini diharapkan juga akan menjadi salah satu solusi ataupun sebagai bahan acuan nantinya baik bagi mahasiswa teknik mesin, trknik industry ataupun bagi industry industri khususnya yang ada didaerah provinsi Aceh, Indonesia.

\section{B. Tujuan Penelitian}

Adapun tujuan penelitian ini sebagai berikut :

1. Dapat mendesain dan membuat alat impak jatuh bebas.

2. Dapat melakukan pengujian impak jatuh bebas pada material baja struktur.

3. Dapat menganalisa hasil pengujian impak jatuh bebas pada material baja struktur.

\section{Batasan Masalah}

Agar penelitian ini lebih terarah dan fokus ke tujuan penelitian dengan membatasi pokok permasalahan sebagai berikut :

1. Pipa galvanis sebagai pengarah beban kepada spesimen uji

2. Dimensi pipa Galvanis D $=2$ "

3. Menggunakan rangka besi profil U

4. Menggunakan beban berbentuk setengah bola pada ujungnya

5. Menganalisa ketangguhan material baja Struktur pada saat pengujian impak jatuh bebas.

\section{STUDI PUSTAKA}

\section{A. Baja}

Baja merupakan logam yang paling banyak digunakan dalam teknik, dalam bentuk pelat, pipa,batang, profil dan sebagainya. Secara garis besar baja dapat dikelompokan menjadi dua yaitu baja karbon dan baja paduan. Baja karbon ini terbagi menjadi tiga macam yaitu : baja karbon rendah $(<0,30 \% \mathrm{C})$, baja karbon sedang $(0,30 \%<$ $\mathrm{C}<0,70 \%)$, baja karbon tinggi $(0,70 \%<\mathrm{C}<$ $1,40 \%)$. Sedangkan baja paduan terdiri dari baja paduan rendah dan baja paduan tinggi. Penggunaan dari masing-masing baja berbeda-beda berdasarkan kandungan karbon pada baja tersebut. Baja karbon rendah digunakan untuk kawat, baja profil, sekrup, ulir dan baut. Baja karbon sedang digunakan untuk rel kereta api, poros roda gigi, dan suku cadang 
yang berkekuatan tinggi, atau dengan kekerasan sedang sampai tinggi. Baja karbon tinggi digunakan untuk perkakas potong seperti pisau, milling cutter, reamers, tap dan bagian-bagian yang harus tahan gesekan (Haryadi, 2005).

\section{A. Sifat Material}

Sifat mekanik sangat di pengaruhi oleh struktur logam,misalnya suatu paduan logam atau paduan (dengan komposisi kimia tertentu) akan mempunyai sifat mekanik material yang berubah dan berbeda bila struktur mikronya berubah. Dan mempengaruhi kekerasan atau keuletan pada benda kerja. (Dimas \& Ritonga, 2016).

\section{B. Sifat Mekanik Logam}

Sifat mekanik merupakan salah satu faktor penting yang mendasari pemilihan material, dalam setiap perencanaan. Sifat mekanik dapat diartikan reaksi beban atau kemampuan logam untuk menahan beban yang diberikan, baik beban statis atau dinamis pada suhu biasa, suhu tinggi maupun suhu dibawah $0{ }^{\circ} \mathrm{C}$. Beban statis adalah beban yang tetap, baik besar maupun arahnya pada setiap saat, sedangkan beban dinamis adalah beban yang besar dan arahnya berubah menurut waktu. Beban dapat berupa beban tarik, tekan, lentur, puntir, geser, dan kombinasi dari beban tersebut. Sementara itu beban dinamis yaitu beban berubah-ubah (Susanto, 2014).

\section{Sifat Fisis}

Sifat fisis adalah kemampuan logam terhadap peristiwa-peristiwa fisika (Basir, 2008). Adapun sifat-sifat fisika tersebut antara lain adalah:

a. Titik lebur Titik lebur merupakan temperatur dimana logam akan meleleh dan akhirnya mencair akibat panas yang diberikan

b. Kepadatan Faktor yang mempengaruhi dari kepadatan ini adalah berat dari atom dan jarak antar atom dari unsur-unsur pembentuknya. Semakin rapat jarak antar atom, maka nilai kepadatannya semakin tinggi.

c. Daya hantar panas Merupakan kemampuan logam menghantarkan panas. Pada aplikasinya dibedakan menjadi konduktor, semi konduktor dan isolator. Daya hantar panas ini sebanding dengan kemampuan material untuk mengalirkan listrik.

d. Daya hantar listrik Merupakan kemampuan logam untuk dialiri maupun mengalirkan arus listrik. Daya hantar listrik pada aplikasinya dibedakan menjadi konduktor, semikonduktor, dan isolator

\section{Baja struktur}

Baja adalah material yang banyak digunakan dalam konstruksi mesin, karena memiliki sifat ulet mudah dibentuk, kuat maupun keras. Baja struktur dikelompokan dalam: baja karbon multi-fungsi (A36), baja karbon struktur (A529), baja karbon kekuatan tinggi dengan bahan tambahan rendah (A572), baja struktur tahan korosi kekuatan tinggi dengan bahan tambahan rendah (A242 dan A588), dan pelat baja dengan pendinginan dan penempaan (A514 dan A852). Dalam paragraf berikut akan dijelaskan mengenai 7 klasifikasi baja ini. Tabel 1.1 memperlihatkan fenomena bahwa semakin tebal baja digiling akan semakin kuat. Elemen yang tebal cenderung akan lebih getas dan kecepatan pendinginan menyebabkan mikrostruktur baja menjadi lebih kasar. Tabel 1.2 yang diambil dari SNI 03-1729-2002 menampilkan sifat mekanis baja structural (Yuwono, 2009).

Salah satunya adalah baja dengan kadar karbon rendah (baja ST 42). Baja ST 42 ini merupakan jenis baja konstruksi dengan tensile strength 40 $\mathrm{kg} / \mathrm{mm} 2$. Baja ini memiliki kandungan karbon (C) sebesar $0,10 \%$, jadi termasuk baja karbon rendah. Baja ini sangat luas pemakaiannya, sebagai baja konstruksi umum, untuk baja profil rangka bangunan, baja tulangan beton, rangka kendaraan, mur baut, pelat, pipa, dan lain-lain. Strukturnya terdiri dari ferrit dan perlite, sehingga baja ini 
kekuatannya relatif rendah, lunak namun keuletannya tinggi, mudah dibentuk dan di machining (Kaban, 2013).

\section{E. Pengertian Uji Impak}

Menurut Dieter, \& Schmidt (2009) uji impak digunakan dalam menentukan kecenderungan material untuk rapuh atau ulet berdasarkan sifat ketangguhannya. Hasil uji impak juga tidak dapat membaca secara langsung kondisi perpatahan batang uji, sebab tidak dapat mengukur komponen gaya-gaya tegangan tiga dimensi yang terjadi pada batang uji. Hasil yang diperoleh dari pengujian impak ini, juga tidak ada persetujuan secara umum mengenai interpretasi atau pemanfaatannya. Sejumlah uji impak batang uji bertakik dengan berbagai desain telah dilakukan dalam menentukan perpatahan rapuh pada logam. Metode yang telah menjadi standar untuk uji impak ini ada 2 , yaitu uji impak metode Charpy dan metode Izod. Metode charpy banyak digunakan di Amerika Serikat, sedangkan metode izod lebih sering digunakan di sebagian besar dataran Eropa (Nurdin, 2009).

\section{F. Gerak Lurus}

Perpindahan adalah perubahan kedudukan. Hal ini merupakan besaran vektor mencakup jarak dan arah. Kecepatan adalah laju perubahan kedudukan terhadap waktu. Hal ini juga merupakan besaran vektor mencakup jarak, arah dan waktu (Mott, 2009)

Percepatan seragam dimiliki partikel yang mengalami perubahan kecepatan yang sama dalam selang waktu yang sama berturut-turut tidak perduli betapa kecilnya selang waktu. Satuan perpindahan diukur dalam meter $[\mathrm{m}]$, kecepatan diukur dalam meter per detik $[\mathrm{m} / \mathrm{s}]$, percepatan diukur dalam meter per detikkwadrat $2\left[\mathrm{~m} / \mathrm{s}^{2}\right]$, persamaan gerakan lurus percepatan seragam. Penjelasannya dapat dilihat pada Gambar 2.1.

Katakan v0 kecepatan awal, v kecepatan akhir, a percepatan, $\mathrm{t}$ waktu dan $\mathrm{s}$ perpindahan kecepatan pertengahan $=$ perpindahan $/$ waktu .

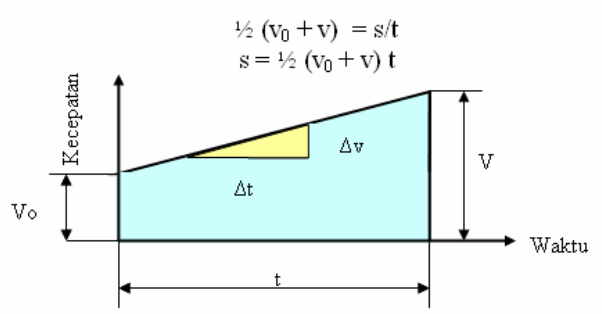

Gambar 1. Diagram Kecepatan - Waktu

Perpindahan digambarkan dengan luas daerah di bawah grafik kecepatan.

$$
\frac{\Delta v}{\Delta t}=a ; v=v_{o}+\frac{\Delta v}{\Delta t} ; \quad v=v_{o}+a t
$$

Penggantian $\left(\mathrm{v}_{0}+\right.$ at $)$ untuk $\mathrm{v}$ di dalam persamaan (1),

$$
s=v_{0} t+\frac{1}{2} a t^{2}
$$

Penggantian $\frac{v-v 0}{a}$ untuk t di dalam persamaan 2.2.

$$
v^{2}=v_{0}^{2}+2 \text { as }
$$

Bila $v_{0}=0$, maka :

$$
\begin{aligned}
& v^{2}=0+2 a s \\
& v=2 a s
\end{aligned}
$$

Untuk jatuh bebas maka $\mathrm{a}=\mathrm{g}$ dan $\mathrm{s}=\mathrm{h}$, sehingga :

$$
V=\sqrt{2 \mathrm{as}}
$$

Di mana: $\quad \mathrm{v}=$ kecepatan benda jatuh $(\mathrm{m} / \mathrm{s})$

$\mathrm{h}=\operatorname{gravitasi}\left(\mathrm{m} / \mathrm{s}^{2}\right)$

$\mathrm{g}=$ ketinggian jatuh benda $(\mathrm{m})$.

\section{G. Energi}

Energi didefinisikan sebagai kesanggupan untuk melakukan kerja.Prinsip kekekalan energi menyatakan bahwa energi tidak dapat diciptakan atau dirusak (Shigley, 1994). Dalam hal ini terdapat dua bentuk energi mekanik, yaitu:

1. Energi potensial (Ep), yaitu energi yang dapat dimiliki benda berdasarkan (tinggi) benda Besarannya dapat ditentukan dengan rumus:

$$
E_{P}=m \cdot g \cdot h
$$

di mana: $E p=$ energi potensial (joule) 


$$
\begin{aligned}
\mathrm{m} & =\text { massa benda }(\mathrm{kg}) \\
\mathrm{g} & =\text { gaya gravitasi }\left(9,81 \mathrm{~m} / \mathrm{s}^{2}\right) \\
\mathrm{h} & =\text { kedudukan/ ketinggian benda }(\mathrm{m})
\end{aligned}
$$

2. Energi kinetik (Ek), yaitu energi yang dapat dimiliki benda. Besarannya dapat ditentukan dengan rumus:

$$
E k=\frac{1}{2} m \cdot v^{2}
$$

$$
\begin{aligned}
\text { di mana: } \mathrm{Ek} & =\text { energi kinetik (joule) } \\
\mathrm{m} & =\text { massa benda }(\mathrm{kg}) \\
\mathrm{v} & =\text { kecepatan benda jatuh }(\mathrm{m} / \mathrm{s})
\end{aligned}
$$

\section{H. Mengetahui Energi Yang Diserap}

Untuk mengetahui energi yang diserap oleh spesimen dapat dihitung dengan rumus:

$$
E=E p+E k
$$

$$
\begin{aligned}
\text { Dimana : } & \text { E }=\text { Energi yang diserap }(\mathbf{J}) \\
& \text { Ep }=\text { Energi potensial }(\mathbf{J}) \\
& \text { Ek }=\text { Energi kinetik }(\mathbf{J})
\end{aligned}
$$

\section{Harga Impak}

Kemampuan suatu benda dalam menyerap Gaya Impak diketahui dengan melakukan pengujian impak (Susanto, 2016). Untuk mengetahui harga impak digunakan rumus sebagai berikut :

$$
H I=\frac{E}{A}
$$

Dimana : $\mathrm{HI}=$ Harga impak $\left(\mathrm{J} / \mathrm{m}^{2}\right)$

$\mathrm{E}=$ Energi yang diserap $(\mathrm{J})$

$\mathrm{A}=$ Luas penampang spesimen $\left(\mathrm{m}^{2}\right)$

Luas penampang spesimen (A) diperoleh dari :

$$
A=b \times h
$$

Dimana : $b=0,010 \mathrm{~m}$

$$
\mathrm{h}=0,004 \mathrm{~m}
$$

\section{J. Implus}

Impuls sebuah gaya konstan adalah hasil kali gaya dengan selang waktu yang diperlukan gaya bekerja, dituliskan dengan diperlukan, atau dengan rumus (Susanto, 2016) :

$$
F=\frac{m \cdot v}{t}
$$

Maka impuls $=$ perubahan momentum

$$
I=F \cdot t=m \cdot v
$$

Di mana: $\mathrm{m}=$ massa $(\mathrm{kg})$

$$
\mathrm{v}=\text { kecepatan benda bergerak }(\mathrm{m} / \mathrm{s})
$$

\section{K. Momentum}

Sebuah benda bergerak dikatakan mempunyai momentum yang dinyatakan dengan hasil kali massa benda dengan kecepatan benda. Momentum $=$ massa $\mathrm{x}$ kecepatan.

$$
M=m \cdot v
$$

$$
\text { Di mana } \quad \begin{aligned}
\mathrm{M} & =\operatorname{momentum}(\mathrm{kg} \cdot \mathrm{m} / \mathrm{s}) \\
\mathrm{m} & =\operatorname{massa}(\mathrm{kg}) \\
& \mathrm{v}=\operatorname{kecepatan} \text { benda bergerak }(\mathrm{m} / \mathrm{s})
\end{aligned}
$$

\section{METODE}

\section{A. Prinsip Kerja Alat Impak Jatuh Bebas}

Pada penelitian ini beban dijatuhkan dari ketinggian $1500 \mathrm{~mm}$ melalui lubang pipa mengenai limit switch lalu stopwatch mulai menghitung waktu dan ketika beban menyentuh limit switch yang berada dibawah maka waktu pada stopwatch akan berhenti dengan sendirinya (Pratama \& Ritonga 2016). Pipa digunakan untuk agar beban tetap mengarah lurus jatuh pada spesimen uji , selain itu pipa digunakan juga sebagai tempat melekatnya limit switch dan stopwatch. Setelah Beban menghantam spesimen,akan terjadi deformasi (perubahan bentuk) pada sepesimen uji karena terjadinya beban kejut (gaya impak) akibat beban berbenturan dengan specimen, gambar desain alat uji impak jatuh bebas dapat dilihat pada Gambar 2. dibawah ini. 


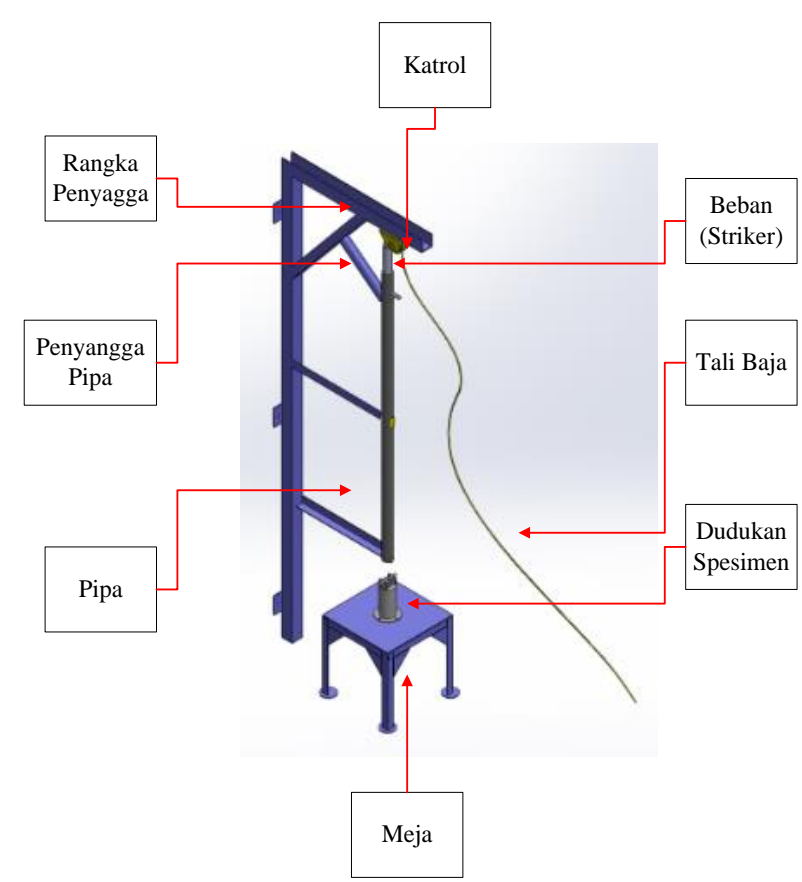

Gambar 2. Desain alat Uji Impak Jatuh Bebas

\section{B. Tempat Pembuatan Produksi}

Adapun tempat pembuatan alat uji impak jatuh bebas ini akan dilaksanakan di lab produksi dan Perawatan Teknik Mesin Politeknik Lhokseumawe dan bengkel-bengkel lain.

\section{Proses Pembuatan Alat}

Dalam alat uji impak jatuh bebas ada beberapa langkah-langkah yang harus dibuat yaitu :

1. Pembuatan Beban dilakukan mengunakan mesin bubut hingga mencapai diameter $42 \mathrm{~mm}$ panjang $245 \mathrm{~mm}$ dan pada ujungnya di bentuk setengah bola.

2. Pembuatan meja, memotong mesi siku sepanjang 400 x $400 \mathrm{~mm}$ lau dilas pada besi siku hingga membentuk meja dan pada atasnya dilaslah pelat dengan tebal $5 \mathrm{~mm}$.

3. Pembuatan rangka penyangga, memotong besi Unp sepanjang $2500 \mathrm{~mm}$ dan $800 \mathrm{~mm}$ lau dilas membentuk siku pada ujungnya diberi sangahan besi Unp.

4. Pembuatan Dudukan pipa, memotong 2 besi siku sepanjang $540 \mathrm{~mm}$ las besi siku ke rangka penyangga lau las pipa pada besi siku.

5. Pembuatan dudukan Spesimen, Besi round bar dilubangi dengan bubut dengan bubut dalam dengan diameter 37 mmpada bagian satunya dilas plane dengan diameter $120 \mathrm{~mm}$.

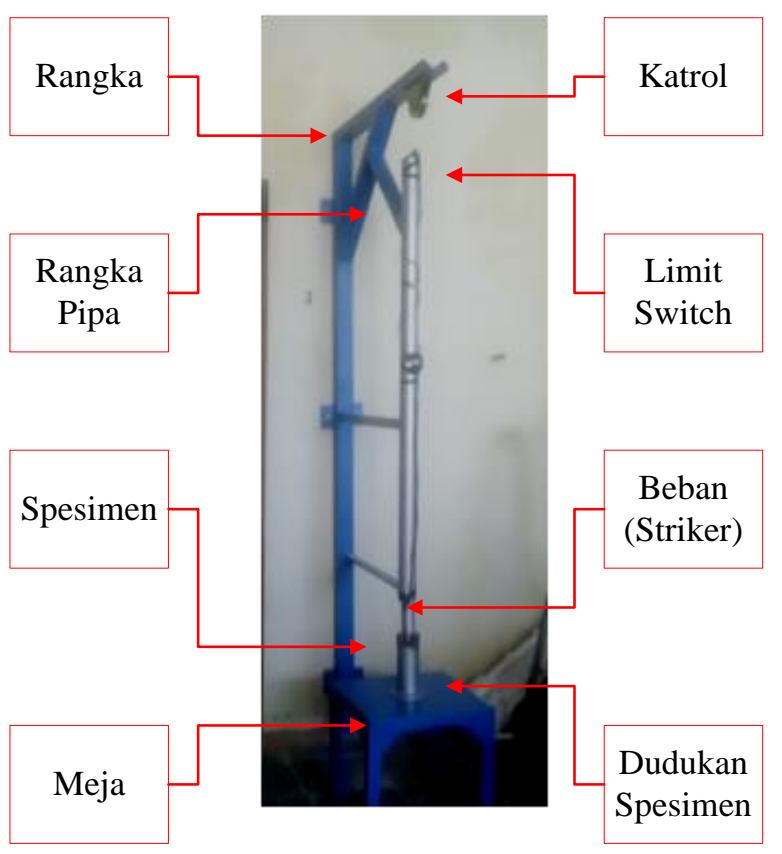

Gambar 3. Hasil pembuatan Alat Uji impak

\section{Metode Pengambilan Data}

Pada tahap ini langkah-langkah yang dilakukan adalah sebagai berikut :

1. Menyiapkan spesimen uji dimensinya: $\mathrm{D}=10$ $\mathrm{mm}, \mathrm{T}=100 \mathrm{~mm}$

2. Buat takikan pada spesimen sedalam $4 \mathrm{~mm}$

3. Pasang spesimen ke dudukan spesimen

4. Selaraskan antara dudukan spesimen dan beban yang akan menghantam

5. Atur posisi limit switch pada tempatnya

6. Set waktu stopwatch pada waktu 0 detik

7. Jatuhkan beban dari keetinggian $1,5 \mathrm{~m}$

8. Hitung waktu benda jatuh dengan stopwatch

9. Menghitung kecepatan, energi kinetik, energi potensial, percepatan dan gaya dengan rumus sebagai berikut :

10. Lihat dan amati setelah perubahan bentuk spesimen yang telah dilakukan percobaan

11. Ulangi ke pengujian berikutnya

\section{HASIL DAN PEMBAHASAN}

\section{A. Hasil Pengujian Impak Jatuh Bebas}


Berdasarkan hasil pengujian impak jatuh bebas dilakukan pengamatan visual didapatkan sebagai berikut.

\section{Gambar Hasil Pengujian 1 Impak jatuh Bebas.}

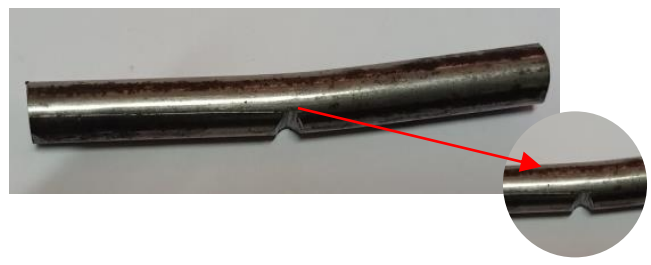

Gambar 4. Hasil pengujian 1 Uji impak jatuh bebas

Dilihat pada gambar 4.1 terjadinya pembengkokan akibat gaya impak yang diberikan, tetapi pembengkokakan yang terjadi tidak signifikan.

\section{Gambar Hasil Pengujian 2 Impak jatuh Bebas.}

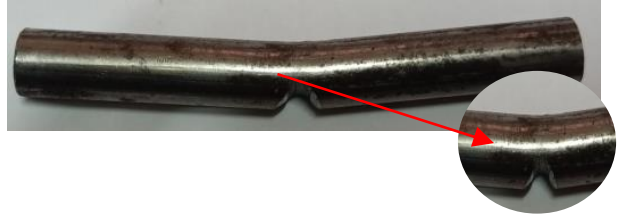

Gambar 5. Hasil pengujian 2 Uji impak jatuh bebas

Dilihat pada Gambar 5. terjadinya pembengkokan akibat gaya impak yang diberikan, tetapi pembengkokakan yang terjadi lebih besar dibandingkan dengan pengujian 1 .

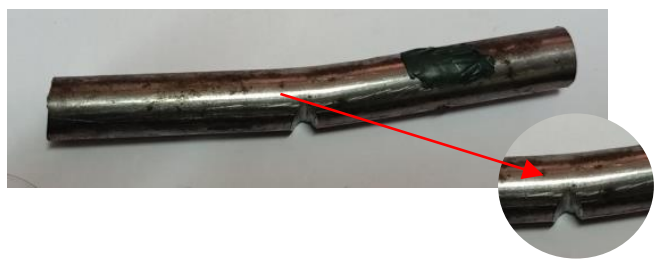

Gambar 6. Hasil pengujian 3 Uji impak jatuh bebas

Dilihat pada gambar 6 terjadinya pembengkokan akibat gaya impak yang diberikan, tetapi pembengkokakan yang terjadi lebih besar
Penerapan General English dan English for Specific Purposes di Perguruan Tinggi Khususnya pada Pendidikan Vokasi

dibandingkan dengan pengujian 1 , tetapi apabila dibandingkan dengan pengujian 2 pengujian 3 terjadi lebih kecil pembengkokan.

\section{B. Perhitungan}

Setelah mendapatkan data hasil pengujian, maka perlu dilakukan perhitungan. Perhitungan data dari hasil pengujian ini bertujuan untuk mengetahui kekuatan material Baja Struktur pada alat uji impak jatuh bebas dengan variasi beban dan ketinggian, yang terdiri dari perhitungan : Kecepatan jatuh (v), Energi potensial (Ep), Energi kinetik (Ek), Energi yang diserap (E), Harga impak (HI), Ketangguhan (Er). Dari hasil perhitungan ini nantinya akan dilakukan analisa. Dalam perhitungan ini diasumsikan $\rho=7850 \mathrm{~kg} / \mathrm{m}^{3}, \mathrm{~A}=$ $40 \mathrm{~mm}^{2}, \mathrm{~F}=23,52 \mathrm{~N}$ dan $g=9,8 \mathrm{~m} / \mathrm{s}^{2}$. Data yang diambil sebagai perhitungan berikut ini adalah pada spesimen baja struktur dengan panjang $=0,1 \mathrm{~m}$, diameter $=0,01 \mathrm{~m}$ dan kedalaman takik $=4 \mathrm{~mm}$ dengan sudut $45^{\circ}$ dengan pemberian beban kejut.

Spesimen baja struktur pada jarak ketinggian 2 $\mathrm{m}$ dan beban $2,4 \mathrm{~kg}$.

Dimana $: \mathrm{t}=1,52 \mathrm{~s}$

a. Kecepatan jatuh

$v=g \cdot t$

$v=9,8.1,52$

$\mathrm{v}=14,896 \mathrm{~m} / \mathrm{s}$

b. Energi yang diserap

$E=E K_{1}+E P_{1}$

$E=\frac{1}{2} \cdot m \cdot\left(v_{s 2}-v_{s 1}\right)^{2}+m \cdot g \cdot\left(h_{2}-h_{1}\right)$

$E=\frac{1}{2} \cdot 2,4 \mathrm{~kg} \cdot(14,89 \mathrm{~m} / \mathrm{s}-0)^{2}$ $+2,4 \mathrm{~kg} \cdot 9,8 \mathrm{~m} / \mathrm{s}^{2} \cdot(1,5 \mathrm{~m}-0)$

$\mathrm{E}=266,05 \mathrm{~kg} \cdot \mathrm{m}^{2} / \mathrm{s}^{2}+35,28 \mathrm{~kg} \cdot \mathrm{m}^{2} / \mathrm{s}^{2}$

$\mathrm{E}=301,33 \mathrm{~J}$

c. Harga impak

$\mathrm{HI}=\frac{\mathrm{E}}{\mathrm{A}}$

$\mathrm{HI}=\frac{301,33 \mathrm{~J}}{40 \mathrm{~mm}^{2}}$

$\mathrm{HI}=7,53 \mathrm{~J} / \mathrm{mm}^{2}$ 
d. Implus

$$
\begin{aligned}
& \mathrm{I}=\mathrm{F} \cdot \mathrm{t} \\
& \mathrm{I}=23.52 \mathrm{~N} \cdot 1.52 \mathrm{~s} \\
& \mathrm{I}=35,75 \mathrm{Ns}
\end{aligned}
$$

e. Momentum

$$
\begin{aligned}
& \mathrm{M}=\mathrm{m} \cdot \mathrm{v} \\
& \mathrm{M}=2,4 \mathrm{~kg} \cdot 14,90 \mathrm{~m} / \mathrm{s} \\
& \mathrm{M}=35,76 \mathrm{~kg} \cdot \mathrm{m} / \mathrm{s}
\end{aligned}
$$

Untuk keseluruhan data pengujian. Maka didapat hasilnya yang tertera pada tabel berikut.

Tabel 1. Hasil perhitungan pada massa $=2,4 \mathrm{~kg}$

\begin{tabular}{|c|c|c|c|c|c|c|}
\hline \multicolumn{7}{|c|}{ Massa $=2,4 \mathrm{~kg}$ dan $\mathrm{h}=1,5 \mathrm{~m}$} \\
\hline No & $\mathrm{t}(\mathrm{s})$ & $\begin{array}{c}\mathrm{v} \\
(\mathrm{m} / \mathrm{s})\end{array}$ & $\mathrm{E}(\mathrm{J})$ & $\begin{array}{c}\mathrm{HI} \\
\left(\mathrm{J} / \mathrm{mm}^{2}\right)\end{array}$ & $\begin{array}{c}\mathrm{M} \\
(\mathrm{kg} \cdot \mathrm{m} / \mathrm{s})\end{array}$ & $\begin{array}{c}\mathrm{I} \\
(\mathrm{Ns})\end{array}$ \\
\hline 1 & 1,52 & 14,9 & 301,33 & 7,53 & 35,76 & 35,75 \\
\hline 2 & 1,66 & 16,27 & 352,94 & 8,82 & 39,04 & 39,04 \\
\hline 3 & 1,55 & 15,19 & 212,16 & 7,8 & 36,46 & 36,46 \\
\hline
\end{tabular}

\section{KESIMPULAN DAN SARAN}

\section{A. Kesimpulan}

1. Telah dapat mendesain dan membuat mesin Uji Impak Jatuh Bebas pada material baja struktur dengan beban $2,4 \mathrm{~kg}$ dan ketinggian $1,5 \mathrm{~m}$ sesuai dengan perhitungannya.

2. Telah dapat melakukan pengujian pada mesin Uji Impak Jatuh Bebas pada material baja struktur dengan beban $2,4 \mathrm{~kg}$ dan ketinggian 1,5 m

3. Telah dapat menganalisa material baja struktur dengan beban $2,4 \mathrm{~kg}$ dan ketinggian $1,5 \mathrm{~m}$ sesuai dengan perhitungan diatas.

4. Perilaku mekanis ditunjukkan dengan terjadinya pembengkokan pada specimen akibat benturan beban (striker) saat pengujian dilakukan

\section{B. Saran}

Adapun saran yang dapat saya suarakan adalah sebagai berikut :

1. Alat uji impak jatuh bebas ini kami sadar masih terdapat banyak kekurangan kekurangan, oleh sebab itu apabila ada yang hendak merancanakan ulang, maka bisa ditambah load cell agar alat uji impak ini lebih efisien.

2. Saat mengoperasikan alat harus berhati - hati dengan materialnya jangan sampai terpantul keatas anda karena alat ini belum dilengkapi dengan kerangka besi

3. Lakukan pengecekan pada pin penyangga pendempul karena bisa jadi pin nya tidak mampu menahan bebannya lagi.

4. Untuk penelitian selanjutnya kami sarankan agar meletakkan sensor diletakkan pada pipa dengan jarak yang lebih efesien.

\section{DAFTAR PUSTAKA}

Basir, A. (2008). Analisis Hasil Pembuatan Koin Aluminium Dengan Proses Analisis Hasil Pembuatan Koin Aluminium Dengan Proses Blanking Menggunakan Beban Impak Benda Jatuh Bebas (Master's thesis) Sumatra Utara, Universitas Negeri Sumatra Utara.

Dieter, G.E., \& Schmidt, L.C., 2009. Engineering design. Boston: McGraw-Hill Higher Education.

Haryadi, G. (2005). Pengaruh Suhu Tempering Terhadap Kekerasan Struktur Mikro Dan Kekuatan Tarik Pada Baja K-460. Rotasi, 7(3), 1-10.

Kaban, N. L. (2013). Analisa Kekuatan Impak Concrete Foam Dengan Variasi Komposisi Poliuretan Yang Diperkuat Serat Tandan Kosong Kelapa Sawit Akibat Impak Jatuh Bebas (Master's thesis) Sumatra Utara, Universitas Negeri Sumatra Utara.

Mott, R. L. (2009). Elemen-Elemen Mesin Dalam Perancangan Mekanis. Yogyakarta: Penerbit ANDI.

Nurdin. (2009). Pengujian impak metode charpy. Lhokseumawe : Politeknik Negeri Lhokseumawe.

Pratama, D., \& Ritonga, D. A. A., (2016). 
Dailami, Hamdani, Samsul Bahri

Pengaruh gaya impak jatuh bebas terhadap kekuatan baja st 60 (1).

Shigley, K. (1994). Perencanaan Teknik Mesin. Jakarta: Erlangga.

Susanto, A. (2014). Analisis kepadatan pada proses pelapisan nikel krom dengan variasi kuat arus dan lama pencelupan baja st 42 . Jurnal Teknik Mesin, 4(3).

Susanto, E. (2016). Momentum, Impuls dan Tumbukan. 1. Semarang: Universitas Negeri Semarang.

Yuwono, A. H. (2009). Buku Panduan Praktikum Karakteristik Material 1 Pengujian Merusak (Destructive testing).
Penerapan General English dan English for Specific Purposes di Perguruan Tinggi Khususnya pada Pendidikan Vokasi

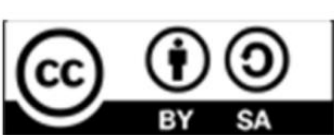

Copyright (C) 2020

Vocatech: Vocational Education and Technology Journal This works is licensed under a Creative Common Attribution-ShareAlike 4.0 